\title{
DIVERSI DALAM SISTEM PERADILAN PIDANA ANAK DI INDONESIA
}

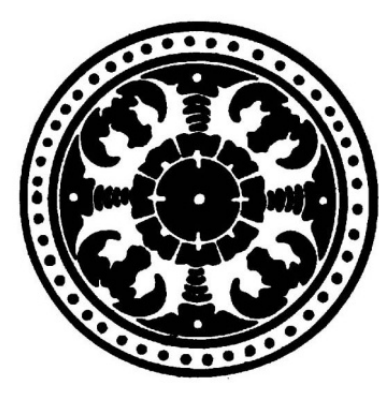

MADE AYU CITRA MAYA SARI

NIM : 0890561032

HUKUM DAN SISTEM PERADILAN PIDANA

PROGRAM PASCA SARJANA UNIVERSITAS UDAYANA PROGRAM STUDI MAGISTER ILMU HUKUM DENPASAR 


\title{
DIVERSI DALAM SISTEM PERADILAN \\ PIDANA ANAK DI INDONESIA
}

\author{
Oleh : \\ Made Ayu Citra Maya Sari, SH
}

\begin{abstract}
The criminal act that happens currently in the society is not done only by adult, even there is a trend that the person who did it was included in the children age. Legally, a call for a person who committed a crime that included in the children age is known as a child who has conflict with law.

One of state's efforts to protect the child who has conflict with law is by implementing the Diversion pattern, that is handling process to a child who has conflict with law is shifted from the formal to be a non-formal process.

This research with the normative research type that is supported by the empirical data has purpose to investigate and study the Diversion ideas in the law protection to the child who has conflict with law, and further to find out the concrete implementation that is drafted in the Law of Children Jurisdiction System these days (Law No. 11 Year 2012) and the application by all law enforcer component and the related institutions that involves in the handling of the cases of child who has conflict with law in due process of law from the level of investigation, prosecution, court session and the development in the Prison for Children.
\end{abstract}

Key words: Diversion, Court, Child.

\section{PENDAHULUAN}

Anak merupakan subyek hukum dan aset bangsa, sebagai bagian dari generasi muda anak berperan sangat strategis sebagai generasi penerus suatu bangsa. Dalam konteks Indonesia, anak adalah penerus citacita perjuangan suatu bangsa. "Peran strategis ini telah disadari oleh masyarakat Internasional untuk melahirkan sebuah konvensi yang intinya menekankan posisi anak sebagai makhluk manusia yang harus mendapatkan perlindungan atas hakhak yang dimilikinya. ${ }^{1}$

Anak juga merupakan harapan dan tumpuan orang tua, harapan bangsa dan negara yang akan melanjutkan tongkat estafet pembangunan serta memiliki peran strategis, mempunyai ciri atau sifat

\footnotetext{
1 Ruben Achmad, 2005, Upaya Penyelesaian Masalah Anak yang Berkonflik dengan Hukum di Kota Palembang, dalam Jurnal Simbur Cahaya Nomor 27 Tahun X, Januari, hal. 24.
} 
khusus yang akan menjamin kelangsungan eksistensi bangsa dan negara pada masa depan. Oleh karena itu, setiap anak harus mendapatkan pembinaan dan perlindungan dari sejak dini, anak perlu mendapat kesempatan yang seluas-luasnya untuk dapat tumbuh dan berkembang secara optimal, baik fisik, mental maupun sosial. Terlebih lagi bahwa masa kanak-kanak merupakan periode penaburan benih, pendirian tiang pancang, pembuatan pondasi, yang dapat disebut juga sebagai periode pembentukan watak, kepribadian dan karakter diri seorang manusia, agar mereka kelak memiliki kekuatan dan kemampuan serta berdiri tegar dalam meniti kehidupan. $^{2}$

Kenakalan anak sudah tidak bisa dipandang lagi sebagai kenakalan biasa, anak-anak banyak melakukan perbuatan yang tergolong tindak pidana, seperti : mencuri, membawa senjata tajam, terlibat perkelahian, terlibat penggunaan narkoba, dan lain-lain. Namun demikian, anak yang melakukan tindak pidana dan

\footnotetext{
${ }^{2}$ Maidin Gultom, 2008, Perlindungan Hukum Terhadap Anak dalam Sistem Peradilan Pidana Anak di Indonesia, Bandung, Refika Aditama, hal. 1.
}

perbuatan yang dilarang oleh hukum, harus ditafsirkan sebagai ketidakmampuan akal (pikiran), fisik (badan) atau moral dan mentalitas yang ada pada diri anak yang ditentukan oleh nilai kodrat. ${ }^{3}$

Seorang anak sesuai sifatnya masih memiliki daya nalar yang belum cukup baik untuk membedakan hal-hal baik dan buruk. Tindak pidana yang dilakukan oleh anak pada umumnya adalah merupakan proses meniru ataupun terpengaruh bujuk rayu dari orang dewasa. Sistem peradilan pidana formal yang pada akhirnya menempatkan anak dalam status narapidana tentunya membawa konsekuensi yang cukup besar dalam hal tumbuh kembang anak. Proses penghukuman yang diberikan kepada anak lewat sistem peradilan pidana formal dengan memasukkan anak ke dalam penjara ternyata tidak berhasil menjadikan anak jera dan menjadi pribadi yang lebih baik untuk menunjang proses tumbuhkembangnya. Penjara justru seringkali

\footnotetext{
3 Wadong, Maulana Hasan, 2000, Advokasi dan Hukum Perlindungan Anak, Grasindo, Jakarta, hal. 68.
} 
membuat anak semakin profesional dalam melakukan tindak kejahatan. ${ }^{4}$

Perspektif sudut pandang psikologis, berbagai sikap dan tindakan sewenang-wenang terhadap anak, membuat mereka menjadi anakanak yang bermasalah sehingga mengganggu proses pertumbuhan / perkembangan secara sehat. Hal ini tidak terlepas dari semakin kompleksnya masalah yang dihadapi anak-anak zaman sekarang, ditambah lagi faktor-faktor penunjang untuk terjadinya proses belajar secara tidak langsung, seperti tayangan-tayangan kekerasan di layar kaca, sampai berita kekerasan serius yang muncul akhirakhir ini. Sementara pada diri seorang anak, proses imitasilah (meniru) paling dominan memberikan pengaruh terhadap dirinya. Bertitik tolak dari kompleksnya permasalahan berkaitan dengan perlindungan yang harus diberikan kepada seorang anak yang bermasalah dengan hukum tentu harus ada upaya dari berbagai pihak untuk menyelamatkan anak bangsa.

${ }^{4}$ M. Joni dan Zulchaina Z. Tanamas, 1995, Aspek Hukum Perlindungan Anak dalam Perspektif Konvensi Hak Anak, Bandung, Citra Aditya Bakti, 1999, hal. 1.
Peraturan perundanganundangan yang telah dibuat oleh pemerintah Indonesia untuk memberikan perlindungan hukum dan hak-hak terhadap anak antara lain : Undang-Undang No. 4 Tahun 1979 tentang Kesejahteraan Anak, UndangUndang Nomor 39 Tahun 1999 tentang Hak Asasi Manusia, UndangUndang Nomor 3 Tahun 1997 tentang Pengadilan Anak, Undang-Undang Nomor 23 Tahun 2002 tentang Perlindungasn Anak, dan terakhir Undang-Undang Nomor 11 Tahun 2012 tentang Sistem Peradilan Anak, dimana secara substansinya semua undang-undang tersebut mengatur hak-hak anak yang berupa : hak hidup, hak atas nama, hak pendidikan, hak kesehatan dasar, hak untuk beribadah menurut agamanya, hak berekspresi, berpikir, bermain, berkreasi, beristirahat, bergaul dan hak jaminan sosial.

\section{METODE PENELITIAN}

Penulisan memakai metode jenis penelitian hukum normatif (normative legal research), yaitu penelitian yang dilakukan atas pasalpasal aturan hukum untuk 
menentukan asas-asas hukum, diversi yang digagas oleh pemerintah mengetahui sinkronisasi vertikal / melalui badan legislatif yang horizontal, mengetahui aspek sejarah dituangkan dalam berbagai produk hukum dan mengetahui perbandingan hukum khusus menyangkut antara sistem-sistem hukum. ${ }^{5} \quad$ perlindungan hukum bagi pelaku anak

\section{HASIL DAN PEMBAHASAN}

\section{Pengertian dan Tujuan Diversi}

Berdasar fenomena serta fakta hukum dari anak yang berkonflik dengan hukum yang terus berkembang mewarnai proses penegakan hukum dan intensitas tindak pidana yang terjadi, maka penulis merumuskan permasalahan seperti :

1. Bagaimana konsepsi ide diversi oleh legislator dalam memberikan perlindungan hukum terhadap anak yang berkonflik dengan hukum?

2. Apakah ide diversi telah diimplementasikan dalam Undang-Undang Nomor 11 Tahun 2012 tentang Sistem Peradilan Pidana Anak tersebut?

Tujuan secara umum penelitian ini untuk mengetahui konsep ide

\footnotetext{
${ }^{5}$ Soerjono Soekanto dan Sri Mamudji, 2009, Penelitian Hukum Normatif, Suatu Tinjauan Singkat, Raja Grafindo Persada, Jakarta, hal. 13.
}

yang bermasalah dengan hukum dalam terlibat konflik hukum. Tujuan secara khusus penelitian ini adalah untuk meneliti penuangan ide-ide diversi dalam Undang-Undang Nomor 11 Tahun 2012 tentang Sistem Peradilan Pidana Anak, sebagai dasar dan acuan penegak hukum dalam proses peradilan bagi anak yang berkonflik dengan hukum.

Ide adalah gagasan, pemikiran tentang suatu objek atau fenomena, sehingga ide diversi dalam hal ini adalah gagasan, pemikiran tentang diversi. Kata diversi berasal dari kata bahasa Inggris Diversion, menjadi istilah diversi. ${ }^{6}$ Istilah diversi dipakai dalam perumusan hasil seminar nasional peradilan anak yang diselenggarakan oleh Fakultas

\footnotetext{
6 Departemen Pendidikan dan Kebudayaan Republik Indonesia, 2005, Pedoman Umum Ejaan Bahasa Indonesia yang Disempurnakan dan Pedoman Umum Pembentukan Istilah. Get. Ke VII, Bandung: Pustaka Setia, hal. 84-87.
} 
Hukum Universitas Padjadjaran

Bandung tanggal 5 Oktober $1996{ }^{7}$

Ide diversi dicanangkan dalam

United Nations Standard Minimum

Rules for the Administration of

Juvenile Justice (SMRJJ) atau The

Beijing Rules (Resolusi Majelis

Umum PBB 40/33 tanggal 29

November 1985), dimana diversi

(Diversion) tercantum dalam Rule

11,1, 11.2 dan Rule 17.4.

\begin{tabular}{lcrr}
\multicolumn{1}{c}{ Ide } & dasar & diversi & atau \\
pengalihan & ini & adalah & untuk \\
menghindari & & efek & negatif
\end{tabular}

pemeriksaan konvensional peradilan

pidana anak terhadap anak, baik efek

negatif proses peradilan maupun efek negatif stigma (cap jahat) proses peradilan, maka pemeriksaan secara konvensional dialihkan, dan kepada anak tersebut dikenakan programprogram diversi. Syarat-syarat dilakukan ide diversi dalam perkara anak, yaitu:

1) pelaku anak yang baru pertama kali melakukan tindak pidana;

2) umur anak relatif masih muda;

3) implementasi bentuk programprogram diversi yang dikenakan pada anak mendapat persetujuan

\footnotetext{
${ }^{7}$ Romli Atmasasmita, 1997 Peradilan Anak di Indonesia, Bandung: Mandar Maju, hal. 201.
}

pada orang tua/wali, maupun anak yang bersangkutan;

4) kejahatan yang dilakukan dapat tindak pidana yang ringan ataupun yang berat (dalam kasus tertentu);

5) anak telah mengaku bersalah melakukan tindak pidana/kejahatan;

6) masyarakat mendukung dan tidak keberatan, atas pengalihan pemeriksaan ini;

7) Jika pelaksanaan program diversi gagal, maka pelaku anak tersebut dikembalikan untuk diperiksa secara formal.

Tindakan diversi dapat dilakukan oleh pihak kepolisian, kejaksaan, pihak pengadilan maupun pembina lembaga pemasyarakatan. Penerapan diversi di semua tingkatan ini diharapkan mengurangi efek negatif (negative effect) keterlibatan anak dalam proses peradilan tersebut. $^{8}$ Ide diversi yang diatur dalam SMRJJ atau The Beijing Rules, mengatur bahwa ide diversi dapat dilakukan tidak hanya terbatas pada kejahatan anak yang ringan saja.

Di bawah ini penulis sebutkan pengertian diversi maupun programprogram diversi, sebagai berikut.

8 Barda Nawawi Arief, 2001, Beberapa Aspek Kebijakan Penegakan dan Pengembangan Hukum Pidana, Citra Aditya Bhakti, Bandung, hal.165. 
Diversion as program and practices which are employed for young people who have initial contact with the police, but are diverstedfrom the traditional juvenile justice processes before children's court adjudication. $^{9}$ (Diterjemahkan oleh penulis sebagai berikut: Diversi adalah suatu program dan latihan-latihan yang mana diajarkan bagi anakanak yang mempunyai urusan dengan polisi, sebagai pengalihan dari proses peradilan anak seperti biasanya, sebelum diajukan ke pemeriksaan pengadilan).

Di Indonesia, istilah diversi pernah dimunculkan dalam perumusan hasil seminar nasional peradilan anak yang diselenggarakan oleh Fakultas Hukum Universitas Padjadjaran Bandung tanggal 5 Oktober 1996. Di dalam perumusan hasil seminar tersebut tentang hal-hal yang disepakati, antara lain "Diversi", yaitu kemungkinan hakim menghentikan atau mengalihkan/tidak meneruskan pemeriksaan perkara dan

9 Kenneth Polk, 2003, "Juvenile Diversion in Australia: A National Review", Sydney Australia, Departement of Juvenile Justice and Held, hal. 2. pemeriksaan terhadap anak selama proses pemeriksaan di muka sidang. ${ }^{10}$

Ide diversi sebagai bentuk pengalihan atau penyampingan penanganan kenakalan anak dari proses peradilan anak konvesional, ke arah penanganan anak yang lebih bersifat pelayanan kemasyarakatan, dan ide diversi dilakukan untuk menghindarkan anak pelaku dari dampak negatif praktek penyelenggaraan peradilan anak. ("persisten delinquent is the result of treating first- offenders ash they were become persistently delinquent. Juvenile justice system processing therefore does more harm than good. $)^{11}$

Selanjutnya dikemukakan Apong Herlina, tentang bagaimana manfaat pelaksanaan program diversi bagi pelaku anak, yang dirinci dalam beberapa uraian. Hal ini dapat dikemukakan sebagai berikut.

1. Helps juveniles learn from their mistake through early intervention (membantu anak-anak belajar dari kesalahannya melalui intervensi selekas mungkin)

10 Romli Atmasasmita, 2003, Peradilan Anak di Indonesia, Bandung: Mandar Maju, hal. 201.

11 Paulus Hadi Suprapto. Op.Cit., hal. 230. 
2. Repairs the harm caused to families, victims and the community (memperbaiki lukaluka karena kejadian tersebut, kepada keluarga, korban dan masyarakat)

3. Incorporates parents, guardians and lessons from everyday life (kerjasama dengan pihak orang tua, pengasuh dan diberi nasehat hidup sehari-hari)

4. Equips and encourages juveniles to make responsible decisions (melengkapi dan membangkitkan anak-anak untuk membuat keputusan untuk bertanggung jawab)

5. Creates mechanism to collect restitution for victims (berusaha untuk mengumpulkan dana untuk restitusi kepada korban)

6. Holds yovith accountable for their actions \& provides learning opportunities regarding cause and effect (memberikan tanggungjawab anak atas perbuatannya, dan memberikan pelajaran tentang kesempatan untuk mengamati akibat-akibat dan efek kasus tersebut)

7. Allows eligible offenders the opportunity to keep their record clean (memberikan pilihan bagi pelaku untuk berkesempatan untuk menjaga agar tetap bersih atas cacatan kejahatan)

8. Reduces burden on court system and jails (mengurangi beban pada peradilan dan lembaga penjara)

9. Curbs juvenile crime (pengendalian anak/remaja). ${ }^{12}$

\footnotetext{
12 Curbs juvenile crime <http:// www.co. Stearns, mn. us/1220. htm.> 22-122007.
}

Di Indonesia tujuan ide diversi yaitu; untuk menghindari penahanan; untuk menghindari cap jahat/label sebagai penjahat; untuk meningkatkan keterampilan hidup bagi pelaku; agar pelaku bertanggung jawab atas perbuatannya; untuk mencegah pengulangan tindak pidana; untuk mengajukan intervensiintervensi yang diperlukan bagi korban dan pelaku tanpa harus melalui proses formal; program diversi akan menghindari anak mengikuti proses-proses sistem pengadilan. Langkah lanjut akan program ini akan menjauhkan anakanak dari pengaruh-pengarun dan implikasi negatif dari proses peradilan tersebut. $^{13}$

\section{Hubungan Diversi dengan}

\section{Restoratif Justice}

Pada dasarnya suatu penegakan hukum akan berhasil dan berjalan maksimal jika tidak terlepas dari tiga pilar yang saling mempengaruhi, yakni memenuhi struktur (structure),

\footnotetext{
13 Apong Herlina dkk, 2004, Perlindungan Terhadap Anak Yang Berhadapan Dengan Hukum Manual Pelatihan Untuk Polisi, Jakarta: POLRI UNICEF, hal. 330.
} 
substansi (substance), dan kultur hukum (legal culture). ${ }^{14}$

Pertama, sistem hukum harus mempunyai struktur. Dalam hal ini sistem hukum yang berubah, namun bagian-bagian sistem itu berubah dengan kecepatan yang berbeda, dan setiap bagian berubah tidak secepat bagian tertentu lainnya. Ada pola jangka panjang yang berkesinambungan struktur sistem hukum, dengan kata lain ini adalah kerangka atau rangkaian, bagian yang tetap bertahan, bagian yang memberi semacam bentuk dan batasan terhadap keseluruhan.

Kedua, sistem hukum mempunyai substansi. Yang dimaksud dengan substansi adalah aturan, norma, dan pola perilaku manusia yang nyata dalam sistem hukum. Dan yang ketiga sistem hukum mempunyai kultur (budaya hukum) adalah sikap manusia terhadap hukum dan sistem hukum, di dalamnya terdapat kepercayaan, nilai, pemikiran, serta harapannya.

Dalam United Nations Standard Minimum Rules for the

14 Achmad Ali, 2002, Keterpurukan Hukum di Indonesia, PT. Ghalia Indonesia, Jakarta, hal. 8.
Administration of Juvenile Justice ("The Beijing Rules") butir 11 menentukan :

Diversi merupakan proses melimpahkan anak pelaku tindak pidana dari sistem peradilan pidana kepada sistem informal seperti mengembalikan kepada lembaga sosial masyarakat, baik pemerintah negara maupun non pemerintah. Tindakan ini dilakukan untuk menghindari efek negatif terhadap jiwa dan perkembangan anak. Diversi dilakukan oleh petugas dengan melakukan kewenangan yang disebut diskresi.

\section{Fakta Kasus Anak yang Berkonflik dengan Hukum}

Penelitian terhadap anak yang berkonflik dengan hukum sebagai fakta hukum yang terjadi seperti penulis temukan datanya, sekaligus sebagai bahan hukum empiris dalam menunjang penelitian hukum normatif.

Di bawah ini dikemukakan dalam tabel, data mengenai tindak pidana yang dilakukan oleh anakanak di wilayah hukum Pengadilan Negeri Denpasar selama kurun waktu tahun 2008 sampai dengan Agustus 2009, dapat digambarkan seperti berikut: 
Tabel 1. Jumlah Tindak Pidana Anak yang terjadi selama 2008 s/d Agst 2012

\begin{tabular}{|c|c|c|c|c|c|c|}
\hline No & Bulan & $\begin{array}{c}\text { Tahun } \\
2008\end{array}$ & $\begin{array}{c}\text { Tahun } \\
2009\end{array}$ & $\begin{array}{l}\text { Tahun } \\
2010\end{array}$ & $\begin{array}{c}\text { Tahun } \\
2011\end{array}$ & $\begin{array}{l}\text { Tahun } \\
2012\end{array}$ \\
\hline 1 & Januari & 2 & 3 & 2 & 11 & 1 \\
\hline 2 & Pebruari & 2 & 7 & 4 & 2 & 3 \\
\hline 3 & Maret & 3 & 1 & 4 & 4 & 6 \\
\hline 4 & April & 4 & 5 & - & 6 & 4 \\
\hline 5 & Mei & 4 & 2 & - & 2 & 3 \\
\hline 6 & Juni & 3 & 5 & 5 & 5 & 4 \\
\hline 7 & $\begin{array}{l}\text { Juli } \\
\end{array}$ & 4 & 4 & 6 & 2 & 9 \\
\hline 8 & Agustus & 3 & 4 & 2 & 3 & 5 \\
\hline 9 & September & 3 & - & 2 & 2 & 3 \\
\hline 10 & Oktober & 12 & - & 2 & 3 & - \\
\hline 11 & Nopember & - & - & - & 10 & - \\
\hline 12 & Desember & 6 & - & - & 6 & - \\
\hline & TOTAL & 46 & 31 & 27 & 56 & 38 \\
\hline
\end{tabular}

Berdasarkan data di atas

menunjukkan bahwa terjadi fluktuasi terhadap jumlah tindak pidana yang dilakukan anak dari tahun ke tahun. Hal ini dapat dilihat dari tabel 1 di atas, tahun 2008 terjadi 46 kasus tindap pidana anak, dan tahun 2009 menurun menjadi 31 kasus, dan tahun 2010 menurun lagi menjadi 27 kasus, namun mengalamai peningkatan yang cukup siginifikan di tahun 2011 menjadi 56 kasus. Peneliti tidak mencari apa yang menyebabkan terjadi peningkatan kasus ini, hanyalah memaparkan terjadinya kasus-kasus mengenai tindak pidana anak. Tahun 2012 sampai dengan bulan Agustus terjadi 38 kasus tindak pidana anak.

Di bawah ini akan dikemukakan tindak pidana anak apa saja yang dilakukan anak dari tahun ke tahun selama lima tahun terakhir.
Tabel 2. Jenis Tindak Pidana Yang Dilakukan Anak Tahun 2008

\begin{tabular}{|c|l|c|c|c|}
\hline No & $\begin{array}{c}\text { Jenis Tindak } \\
\text { Pidana }\end{array}$ & $\begin{array}{c}\text { Jumlah } \\
\text { Pelaku }\end{array}$ & U s i a & Pendidikan \\
\hline 1 & Pencurian & 33 & $14-18$ & SD - SLTA \\
\hline 2 & Kealpaan & 2 & 17 & SLTA \\
\hline 3 & Perkosaan & 1 & 17 & SLTP \\
\hline 4 & Psikotropika & 3 & 17 & SLTA \\
\hline 5 & Perjudian & 3 & 16 & SLTP \\
\hline 6 & Pengeroyokan & 1 & 17 & SLTA \\
\hline 7 & Persetubuhan & 1 & 17 & SLTA \\
\hline 8 & Penganiayaan & 2 & 15 & SD \\
\hline \multicolumn{7}{|c|}{ T O T A L } & 46 & - & - \\
\hline
\end{tabular}

Tabel 3. Jenis Tindak Pidana Yang Dilakukan Anak Tahun 2009

\begin{tabular}{|c|l|c|c|c|}
\hline No & $\begin{array}{c}\text { Jenis Tindak } \\
\text { Pidana }\end{array}$ & $\begin{array}{c}\text { Jumlah } \\
\text { Pelaku }\end{array}$ & U s i a & Pendidikan \\
\hline 1 & Pencurian & 20 & $14-18$ & SD - SLTA \\
\hline 2 & Pengerusakan & 3 & 16 & SLTA \\
\hline 3 & Kealpaan & 5 & 17 & SLTP \\
\hline 4 & Perjudian & 1 & 17 & SLTA \\
\hline 5 & Penganiayaan & 2 & 16 & SLTP \\
\hline \multicolumn{5}{|c|}{ T O T A L } \\
* Sumber : Kejaksaan Negeri Denpasar, data diolah penulis
\end{tabular}

Tabel 4. Jenis Tindak Pidana Yang Dilakukan Anak Tahun 2010

\begin{tabular}{|c|c|c|c|c|}
\hline No & $\begin{array}{l}\text { Jenis Tindak } \\
\text { Pidana }\end{array}$ & $\begin{array}{l}\text { Jumlah } \\
\text { Pelaku }\end{array}$ & Us i a & Pendidikan \\
\hline 1 & Pencurian & 23 & $14-17$ & SD - SLTA \\
\hline 2 & Penganiayaan & 1 & 17 & SLTA \\
\hline 3 & Perjudian & 1 & 17 & SLTA \\
\hline 4 & $\begin{array}{l}\text { Perlindungan } \\
\text { Anak }\end{array}$ & 1 & 18 & SLTA \\
\hline 5 & Pengancaman & 1 & 16 & SLTP \\
\hline \multicolumn{2}{|r|}{ TOTAL } & 27 & - & - \\
\hline
\end{tabular}

Tabel 5. Jenis Tindak Pidana Yang Dilakukan Anak Tahun 2011

\begin{tabular}{|c|c|c|c|c|}
\hline No & $\begin{array}{c}\text { Jenis Tindak } \\
\text { Pidana }\end{array}$ & $\begin{array}{l}\text { Jumlah } \\
\text { Pelaku }\end{array}$ & Us i a & Pendidikan \\
\hline 1 & Pencurian & 37 & $14-17$ & SD - SLTA \\
\hline 2 & Perjudian & 2 & 17 & SLTA \\
\hline 3 & Penadahan & 1 & 15 & SLTP \\
\hline 4 & Penganiayaan & 2 & 17 & SLTA \\
\hline 5 & Narkotika & 4 & $16-17$ & SLTP \\
\hline 6 & Pengancaman & 2 & 15 & SLTA \\
\hline 7 & $\begin{array}{l}\text { Melarikan anak } \\
\text { di bawah umur }\end{array}$ & 1 & 15 & SLTA \\
\hline 8 & $\begin{array}{l}\text { Perlindungan } \\
\text { anak }\end{array}$ & 3 & 16-17 & SD \\
\hline 9 & $\begin{array}{l}\text { Kelalaian } \\
\text { menyebabkan } \\
\text { matinya orang } \\
\text { lain }\end{array}$ & 1 & 17 & \\
\hline 10 & pengeroyokan & 3 & 14 & SD \\
\hline \multicolumn{2}{|r|}{ TOT A L } & 46 & - & - \\
\hline
\end{tabular}


Tabel 6. Jenis Tindak Pidana Yang Dilakukan Anak s/d Tahun 2011

\begin{tabular}{|c|c|c|c|c|}
\hline No & $\begin{array}{c}\text { Jenis Tindak } \\
\text { Pidana }\end{array}$ & $\begin{array}{l}\text { Jumlah } \\
\text { Pelaku }\end{array}$ & Usia & Pendidikan \\
\hline 1 & Pencurian & 15 & $14-18$ & SD - SLTA \\
\hline 2 & Narkotika & 2 & 17 & SLTA \\
\hline 3 & $\begin{array}{l}\text { Perlindungan } \\
\text { anak }\end{array}$ & 18 & 17-18 & SLTP-SLTA \\
\hline 4 & Pelayaran & 1 & 17 & SD \\
\hline 5 & $\begin{array}{l}\text { Kelalaian } \\
\text { menyebabkan } \\
\text { matinya orang } \\
\text { lain }\end{array}$ & 2 & 17 & SLTA \\
\hline & TOTAL & 38 & - & - \\
\hline
\end{tabular}

4. Konsepsi Ide Diversi Oleh Legislator Dalam Beberapa Ketentuan Peraturan Perundang-Undangan Pidana Tentang Anak Sebagai Kebijakan Pidana di Indonesia

Kejadian tentang implementasi ide diversi dalam ketentuan (kebijakan formulasi) sistem peradilan pidana anak, berupa ketentuan yang langsung mengatur sistem peradilan pidana anak dan ketentuan yang tidak langsung mengatur sistem peradilan pidana anak. Kebijakan formulasi yang langsung mengatur sistem peradilan pidana anak terdiri dari hukum pidana materiel anak, hukum pidana formal anak, dan hukum pelaksanaan sanksi hukum pidana anak. Oleh karena itu, uraian dalam sub bab ini secara berturut-turut dikemukakan tentang: 1. Ide diversi dalam kebijakan formulasi hukum pidana materiel anak; 2. Ide diversi dalam kebijakan formulasi hukum pidana formal anak; 3. Ide diversi dalam kebijakan formulasi hukum pelaksanaan sanksi hukum pidana anak; 4. Ide diversi dalam ketentuan (kebijakan formulasi) yang tidak langsung mengatur sistem peradilan pidana anak.

\section{a. Ide Diversi dalam Kebijakan Formulasi Hukum Pidana \\ Materiel Anak}

Hukum pidana materiel memuat aturan-aturan yang menetapkan dan merumuskan perbuatan-perbuatan yang dapat dipidana, aturan-aturan yang memuat syarat-syarat untuk dapat menjatuhkan pidana dan ketentuan mengenai pidana. ${ }^{15}$ Selain mengatur memuat syarat-syarat untuk dapat menjatuhkan pidana, maka hukum pidana materiel juga mengatur tentang syarat-syarat untuk tidak menjatuhkan pidana, atau penghapus pidana.

\section{b. Ide Diversi Terdapat Dalam} KUHP (UU No. 1 Tahun 1946 jo UU No. 73 Tahun 1958)

Sebagaimana telah dikemukakan di dalam bab terdahulu hal. 10 . 
bahwa ide diversi ini merupakan pemberian kewenangan bagi penegak hukum anak, setelah dengan pertimbangan yang layak, maka penegak hukum akan mengambil tindakan-tindakan kebijakan dalam menangani atau menyelesaikan masalah pelanggar anak dengan tidak mengambil jalan formal, antara lain menghentikan atau tidak meneruskan/ melepaskan dari proses peradilan pidana atau mengembalikan/ menyerahkan kepada masyarakat dan bentuk-bentuk kegiatan pelayanan sosial lainnya, seperti penyerahan kepada orang tua/wali, pembinaan sosial, pemberian peringatan/nasihat/ konseling, pengenaan denda ataupun memberi ganti rugi kepada korban.

Dengan batasan tersebut, maka hal-hal yang terdapat dalam ide diversi yaitu:

1) Demi untuk kepentingan perlindungan anak, yaitu untuk menghindari efek negatif proses pemeriksaan terhadap anak, maka perkara anak dihentikan dalam tahap penyidikan, penuntutan, pemeriksaan pengadilan dan tahap pelaksanaan putusan pengadilan;
2) Terhadap perkara anak tersebut dilakukan diversi, maka terhadap anak dikenakan programprogram diversi, seperti: a) anak diserahkan kembali untuk dibimbing oleh orang tua/walinya; b) anak tersebut dapat diberi peringatan, nasihat, konseling atau pembinaan sosial lainnya; c) anak dapat dibebani denda ataupun memberi ganti rugi kepada korban.

\section{c. Ide Diversi Terdapat Dalam Undang-Undang Pengadilan} Anak (UU No. 3 Tahun 1997)

UU Pengadilan Anak tidak merumuskan tindak pidana, tetapi mengatur tentang ketentuan sanksi hukum pidana yang dapat dijatuhkan pada anak pelaku tindak pidana (Anak Nakal), sehingga menurut penulis UU Pengadilan Anak merupakan sumber hukum pidana materiel anak pula, walaupun terbatas. Sebagai hukum pidana materiel terbatas, yaitu dengan adanya ketentuan sanksi hukum pidana bagi pelaku anak (Anak Nakal). Ketentuan sanksi bagi Anak Nakal yang diatur dalam UU Pengadilan Anak, sebagai 
ketentuan yang menggantikan sanksi bagi anak-anak sebagaimana diatur dalam Pasal 45, 46, 47 KUHP yang telah dinyatakan tidak berlaku. Sanksi hukum pidana yang dapat dijatuhkan pada Anak Nakal diatur dalam Pasal 22 sampai dengan Pasal 32 UU No. 3 tahun 1997 tentang Pengadilan Anak. Terhadap Anak Nakal hanya dapat dijatuhkan pidana atau tindakan yang ditentukan dalam undang-undang ini.

\section{d. Ide Diversi Dalam Kebijakan} Formulasi Hukum Pidana

\section{Formal Anak}

Hukum pidana formal mengatur bagaimana negara dengan perantara alat-alat perlengkapannya melaksanakan haknya untuk mengenakan pidana. Hukum pidana formal bisa juga disebut hukum acara pidana. Beranjak dari pengertian ini maka hukum pidana formal anak yaitu ketentuan mengatur bagaimana negara dengan perantara alat-alat perlengkapannya (para penegak hukum) melaksanakan haknya untuk mengenakan pidana terhadap anak, sebagaimana diatur dalam hukum acara pidana bagi anak.
1. Keputusan Presiden No. 36 Tahun 1990 tentang Pengesahan Convention On the Rights of The Child (Convensi Hak-Hak Anak)

Ketentuan dalam konvensi Hak-

Hak Anak sebagai standar perlindungan ataupun perlakuan terhadap anak-anak berkonflik dengan hukum (standards regarding children in conflict with the law), dapat dilihat dalama Artikel 37 dan Artikel 40. Prinsip-prinsip perlindungan terhadap anak yang berkonflik dengan hukum dalam Artikel 37.

\section{Implementasi Ide Diversi Dalam Pelaksanaan Sistem Peradilan Pidana Anak (Kebijakan Aplikatif) yang Tertuang Dalam UU No. 11 Tahun 2012 Tentang Sistem Peradilan Pidana Anak}

\footnotetext{
Pelaksanaan sistem peradilan pidana anak di Indonesia secara bertahap dilakukan dengan proses penyelidikan penyidikan, proses penuntutan, proses pemeriksaan di pengadilan dan proses pelaksanaan putusan hakim. Adapun lembagalembaga yang terkait dengan proses pemeriksaan pengadilan anak yaitu: Kepolisian; Balai Pemasyarakatan (Bapas); Kejaksaan; Pengadilan;
} 
Penasehat Hukum dan Lembaga Pemasyarakatan Anak. Sehubungan dengan tahapan dan lembaga yang terkait dengan proses peradilan pidana anak ini, maka uraian dalam sub bab ini tentang implementasi ide diversi dalam pelaksanaan sistem peradilan pidana anak secara bcruirutturut mulai dari tahap penyidikan/ penyelidikan, tahap penuntutan, dan tahap pemeriksaan di pengadilan. Untuk penguraian implementasi ide diversi dalam praktek pelaksanaan pidana di lembaga pemasyarakatan tidak diuraikan.

\section{Implementasi Ide Diversi dalam Bentuk Penyelesaian Secara Kekeluargaan/Perdamaian atau Non-Litigasi pada Tahap Praktik Penyidikan Anak}

Penyidikan adalah serangkaian tindakan penyidik (pejabat polisi negara $\mathrm{R} 1$ atau pejabat pegawai negeri sipil tertentu) dalam hnl dan menurut cara yang diatur dalam undangundang untuk mencari serta mengumpulkan bukti yang dengan bukti itu membuat terang tentang tindak pidana yang terjadi dan guna menemukan tersangkanya. Sebelum dilakukan penyidikan maka dilakukan penyelidikan oleh penyelidik seperti tersurat dalam Pasal 1 angka 1, 1 dan angka 5 UU No. 8 Tahun 1981 tentang KUHAP. Kegiatan penyidikan ini dilakukan oleh atau merupakan kewenangan pihak kepolisian negara RI maupun oleh pejabat pegawai negeri sipil tertentu yang diberi kewenangan khusus, oleh karena itu setidaknya ketentuanketentuan yang digunakan berkaitan untuk mengatur penyidikan ini, yaitu UU No. 8 Tahun 1981 tentang KUHAP; UU No. 3 tahun 1997 tentang Pengadilan Anak; dan UU No. 2 tahun 2002 tentang Kepolisian Negara Republik Indonesia. Di dalam Rancangan Undang Undang tentang peradilan Anak telah disebutkan ketentuan mengenai Diversi yang antara lain disebutkan : Rancangan Undang-Undang Republik Indonesia Nomor ... Tahun ... Tentang Sistem Peradilan Pidana Anak disebutkan dalam Pasal 1 angka 5. "Keadilan Restoratif adalah suatu penyelesaian secara adil yang melibatkan pelaku, korban, keluarga mereka dan pihak lain yang terkait dalam suatu tindak pidana, secara bersama-sama mencari penyelesaian terhadap tindak pidana tersebut dan implikasinya, dengan 
menekankan pemulihan kembali pada keadaan semula dan bukan pembalasan". Sedangkan dalam angka 6 dinyatakan "Diversi adalah suatu pengalihan penyelesaian perkara Anak dari proses peradilan pidana ke proses di luar peradilan pidana".

Pembahasan selanjutnya

tercermin dalam ketentuan :

Pasal 5 :

(1) Sistem Peradilan Pidana Anak wajib mengutamakan pendekatan Keadilan Restoratif.

(2) Sistem Peradilan Pidana Anak sebagaimana dimaksud pada ayat (1) meliputi:

a. penyidikan dan penuntutan pidana Anak dilaksanakan sesuai dengan ketentuan peraturan perundangundangan, kecuali ditentukan lain dalam Undang-Undang ini;

b. pemeriksaan Anak di sidang pengadilan yang diadili dalam sidang Anak yang berada di lingkungan peradilan umum;dan

c. pembinaan, pembimbingan, pengawasan, dan/atau pendampingan selama proses pelaksanaan pidana atau tindakan dan setelah menjalani pidana atau tindakan.

(3) Dalam Sistem Peradilan Pidana Anak sebagaimana dimaksud pada ayat (2) huruf a dan huruf $b$ dapat dilakukan Diversi.
Pasal 6 :

Diversi bertujuan untuk:

a. mencapai perdamaian antara korban dan Anak;

b. menyelesaikan perkara Anak di luar proses peradilan;

c. menghindarkan Anak dari perampasan kemerdekaan;

d. mendorong masyarakat untuk berpartisipasi; dan

e. menanamkan rasa tanggung jawab kepada Anak.

Pasal 7 :

(1) Pada tingkat penyidikan, penuntutan, dan pemeriksaan perkara Anak di pengadilan negeri wajib diupayakan Diversi.

(2) Diversi sebagaimana dimaksud pada ayat (1) dilaksanakan dalam hal tindak pidana yang dilakukan:

a. diancam dengan pidana penjara paling lama 7 (tujuh) tahun; dan

b. bukan merupakan pengulangan tindak pidana.

Pasal 8 :

(1) Proses Diversi dilakukan melalui musyawarah yang melibatkan Anak dan orang tua/walinya, korban dan/atau orang tua/walinya, Pembimbing Kemasyarakatan, dan Pekerja Sosial Profesional berdasarkan prinsip Keadilan Restoratif.

(2) Dalam hal diperlukan, musyawarah sebagaimana dimaksud pada ayat (1) dapat melibatkan Tenaga Kesejahteraan Sosial, dan/atau masyarakat.

(3) Proses Diversi wajib memperhatikan:

a. kepentingan korban; 
b. kesejahteraan dan tanggung jawab Anak;

c. penghindaran stigma negatif;

d. penghindaran pembalasan;

e. keharmonisan masyarakat; dan

f. kepatutan, kesusilaan, dan ketertiban umum.

Pasal 9 :

(1) Penyidik, Penuntut Umum, dan Hakim dalam melakukan Diversi harus mempertimbangkan:

a. kategori tindak pidana;

b. umur Anak;

c. hasil penelitian kemasyarakatan dari Balai Pemasyarakatan;

d. kerugian yang ditimbulkan;

e. tingkat perhatian masyarakat; dan

f. dukungan lingkungan keluarga dan masyarakat.

(2) Keputusan Diversi harus mendapatkan persetujuan korban dan keluarganya serta kesediaan Anak dan keluarganya.

(3) Dalam hal tindak pidana yang dilakukan Anak tidak ada korban, syarat persetujuan korban dan keluarganya sebagaimana dimaksud pada ayat (2) tidak diperlukan.

Pasal 10 :

Hasil kesepakatan Diversi dapat berbentuk:

a. perdamaian dengan atau tanpa ganti kerugian;

b. penyerahan kembali kepada orang tua/wali;

c. keikutsertaan dalam pendidikan atau pelatihan ke lembaga pendidikan, lembaga penyelenggaraan kesejahteraan sosial atau lembaga kesejahteraan sosial; atau

d. pelayanan masyarakat.

Pasal 11:

(1) Kesepakatan sebagaimana dimaksud dalam Pasal 10 dituangkan dalam suatu keputusan yang berlaku sejak dicapainya kesepakatan.

(2) Keputusan Diversi sebagaimana dimaksud pada ayat disampaikan oleh Pembimbing Kemasyarakatan ke pengadilan negeri sesuai dengan daerah hukumnya dalam waktu paling lama 3 (tiga) hari sejak kesepakatan dicapai untuk memperoleh penetapan.

(3) Penetapan sebagaimana dimaksud pada ayat (2) dilakukan dalam waktu paling lama 3 (tiga) hari terhitung sejak diterimanya keputusan Diversi.

(4) Penetapan sebagaimana dimaksud pada ayat (3) disampaikan kepada Pembimbing Kemasyarakatan, Penyidik, Penuntut Umum, atau Hakim dalam waktu paling lama 3 (tiga) hari sejak ditetapkan.

Pasal 12:

Proses peradilan pidana Anak dilanjutkan dalam hal:

a. proses Diversi tidak menghasilkan kesepakatan; atau

b. kesepakatan Diversi tidak dilaksanakan.

Pasal 13 :

Register perkara Anak pada kepolisian, kejaksaan, pengadilan, dan lembaga pemasyarakatan dibuat secara khusus. 
Pasal 14 :

(1) Pengawasan atas proses Diversi dan pelaksanaan kesepakatan yang dihasilkan berada pada atasan langsung pejabat yang bertanggung jawab pada setiap tingkat pemeriksaan.

(2) Selama proses Diversi berlangsung dan setelah Diversi dilaksanakan, Pembimbing Kemasyarakatan wajib melakukan pembimbingan dan pengawasan.

(3) Dalam hal kesepakatan Diversi tidak dilaksanakan dalam waktu yang ditentukan dalam kesepakatan, Pembimbing Kemasyarakatan segera melaporkan kepada pejabat yang bertanggung jawab sebagaimana dimaksud pada ayat (1).

(4) Pejabat yang bertanggung jawab sebagaimana dimaksud pada ayat (3) wajib menindaklanjuti laporan.

Pasal 15 :

(1) Anak yang keberadaan orang tua/walinya tidak diketahui maka pengasuhannya menjadi tanggung jawab kementerian yang menyelenggarakan urusan pemerintahan di bidang sosial dan dinas/instansi sosial.

(2) Pengasuhan sebagaimana dimaksud pada ayat (1) dilaksanakan di Lembaga Penyelenggaraan Kesejahteraan Sosial yang direkomendasikan oleh kementerian yang menyelenggarakan urusan pemerintahan di bidang sosial dan dinas/instansi sosial.

(3) Ketentuan lebih lanjut mengenai tata cara pelaksanaan pengasuhan sebagaimana dimaksud pada ayat
(1) diatur dengan Peraturan Pemerintah.

Pasal 16:

Ketentuan lebih lanjut mengenai pedoman pelaksanaan proses Diversi, tata cara dan koordinasi pelaksanaan Diversi diatur dengan Peraturan Pemerintah.

\section{PENUTUP}

\section{Simpulan}

1. Adapun konsepsi ide Diversi dari legislator atau pihak pemerintah dalam hal ini legislatif bersama eksekutif dalam memberikan perlindungan hukum terhadap anak yang berkonflik dengan hukum telah dituangkan dalam beberapa rangkaian peraturan perundang-undangan menyangkut anak seperti tertuang dalam UU No. 4 Tahun 1979 tentang Kesejahteraan Anak, UU No. 3 Tahun 1979 tentang Pengadilan Anak, UU No. 23 Tahun 2003 tentang Perlindungan Anak, semua aturan di atas mengacu pada konstitusi atau Pasal 34 ayat (1) UUD Negara RI Tahun 1945, UU No. 39 Tahun 1999 
tentang HAM, UU No. 26

Tahun $2000 \quad$ tentang

Pengadilan HAM, beberapa

Konvensi Internasional

tentang Anak, dan The Beijing

Rules. Pada prinsipnya ide

Diversi dikonsepsi untuk

melindungi anak secara

hukum, HAM anak,

menghindari proses peradilan

formal, menghindari

pembalasan dan stigma buruk

dari anak demi kelangsungan

dan perkembangan psikologis

dan fisik anak secara wajar

dan sehat sebagai insan

generasi penerus bangsa.

2. Adapun ide Diversi yang terkonsepsi dalam berbagai aturan formal perundangundangan menyangkut nasib dan kelangsungan serta proses hukum bagi anak yang berkonflik dengan hukum telah terimplementasi penjabarannya dalam UndangUndang Nomor 11 Tahun 2012 tentang Sistem Peradilan Pidana Anak yang merupakan pedoman dan acuan pokok oleh penegak hukum dalam proses peradilan pidana bagi anak yang berkonflik dengan hukum, mulai dari tahap proses penyidikan, penuntutan, persidangan hingga proses pembinaan. Dengan disertai pula pencanangan lembaga khusus terkait yang menangani proses pembinaan. Dengan pula menyediakan Lembaga Pemasyarakatan Khusus Anak, sanksi yang ringan, pencanangan bentuk-bentuk tindakan, straafsort, strafmaat, dan straafmodus khusus yang polanya menyimpang dari prosedural dan jenis yang diterapkan pada orang dewasa. Implementasi ide Diversi ini dalam tiap tahapan proses peradilan pidana anak bertujuan mencapai proses hukum yang adil (due process of law) bagi anak dengan menerapkan serta sasaran keadilan restoratif (restoratif justice). 


\section{Saran}

1. Agar semua komponen bangsa terutama penegak hukum yang menangani kasus-kasus anak yang berkonflik dengan hukum betul-betul menghayati, menyadari dan menerapkan ide Diversi ini demi kelangsungan hidup yang baik bagi anak selaku generasi penerus bangsa yang tidak mesti dan tidak perlu diterapkan prosedural hukum seperti orang dewasa.

2. Agar penegak hukum menerapkan secara konsekuen ide Diversi yang telah tertuang dalam Undang-Undang Nomor 11 Tahun 2012, begitu pula halnya masyarakat luas untuk menyadari bila pelaku suatu tindak pidana adalah menyangkut anak ikut membantu pelaksanaan ide Diversi ini bersama semua aparat penegak hukum dalam proses peradilan anak dengan tujuan tercapainya keadilan restoratif tersebut.

\section{DAFTAR PUSTAKA}

Ali Achmad, 2002, Keterpurukan Hukum di Indonesia, PT. Ghalia, Jakarta.

Apong Herlina dkk, 2004, Perlindungan Terhadap Anak Yang Berhadapan Dengan Hukum Manual Pelatihan Untuk Polisi, POLRI-UNICEF, Jakarta.

Barda Nawawi Arief, 2001, Beberapa Aspek Kebijakan Penegakan dan Pengembangan Hukum Pidana, Citra Aditya Bakti, Bandung.

Dep.Dik.Bud. RI., 2005, Pedoman Umum Ejaan Bahasa Indonesia yang Disempurnakan dan Pedoman Umum Pembentukan Istilah, Pustaka Suci, Bandung.

Kenneth Polk, 2003, Juvenile Diversion in Australia Department of Jouvenile and Held, Sydney - Australia.

Maidin Gultom, 2008, Perlindungan Hukum Terhadap Anak Dalam Sistem Peradilan Pidana Indonesia Anak di Indonesia, Refika Aditama, Bandung.

M. Jony Zulchaina Z. Tanamas, 1995, Aspek Hukum Perlindungan Anak Dalam Perspektif Konvensi Hak Anak, Citra Aditya Bakti, Bandung.

Romli Atmasasmita, 1997, Peradilan Anak di Indonesia, Mandar Maju, Bandung. 
Ruben Achmad, 2005, Upaya Penyelesaian Masalah Anak yang Berkonflik Dengan Hukum di Kota Palembang, Cahaya, Palembang.

Soerjono Soekanto dan Sri Mamudji, 2009, Penelitian Hukum Normatif Suatu Tinjauan Singkat, Raja Grafindo Persada, Jakarta.

Wadong, Maulana Hasan, 2000, Advokasi dan Hukum Perlindungan Anak, Grasindo, Jakarta.

Undang-Undang No. 3 Tahun 1997 Tentang Pengadilan Anak.

Undang-Undang No. 4 Tahun 1997 Tentang Kesejahteraan Anak.

Undang-Undang No. 23 Tahun 2002 Tentang Perlindungan Anak.

Undang-Undang No. 11 Tahun 2012 Tentang Sistem Peradilan Pidana Anak.

Konvensi Hak-Hak Anak Tahun 1989 (Resolusi PBB) Nomor 44/25 Tanggal 5 Desember 1989.

The Beijing Rules (SMRJJ) atau Resolusi Majelis Umum PBB 40/33 tanggal 29 Desember 1985 .

Keputusan Presiden (KEPPRES) Nomor 36 Tahun 1990 Tentang Pengesahan Convention on the Right of the Children (Pengesahan Konvensi Hak Anak).
Curbs juvenile crime <http:// www.co. Stearns, mn. us/1220. htm.> 22-12-2007. 


\section{BIODATA PENULIS}

$\begin{array}{ll}\text { Nama } & : \text { Made Ayu Citra Maya Sari, SH } \\ \text { Alamat Rumah } & : \\ \text { Tempat Bekerja } & : \text { Kejaksaan Negeri Denpasar-Bali } \\ \text { No. HP } & : \\ \text { Email } & :\end{array}$

